NAR article

6-8000 words

Open Archaeology

Acknowledgements: I am sincerely grateful to two anonymous reviewers whose comments on an earlier draft of this paper helped to greatly improve the final text. All mistakes are my own.

\title{
I'll tell you what I want, what I really, really want! Open Archaeology that is Collaborative, Participatory, Public, and Feminist
}

\section{Introduction}

My intention in this paper is quite simple. I wish to defend Open Archaeology that is always Collaborative, Participatory, and Public. In addition, I suggest that it is through an explicitly feminist lens that we will achieve the return to politics and provocation for which some scholars have recently called (González-Ruibal, et al., 2018). I begin by offering some theorisation, contextualisation, and discussion of the terms, 'collaborative', 'participatory', 'public' and 'democratisation', about which there is often confusion. I consider how we might define the limits of inclusivity and openness in the name of democracy. I then further unpack the concept of 'community' in the context of archaeology and discuss some of the reasons why researchers who employ collaborative approaches to the past may be reluctant to openly and publicly acknowledge conflicts and frictions which inevitably arise. Drawing on almost ten years' experience working collaboratively with contemporary homeless people, migrants and refugees, I identify some of the strategies and approaches to community archaeology which I suggest may be more likely to lead to beneficial or positive outcomes.

Later in the article, I explore how an explicitly feminist critical theoretical perspective might improve collaborative community-based participatory research projects, performing important work for women and highlighting the existence and causes of other forms of oppression, many of which - racism, homophobia, Islamophobia, antisemitism - are undergoing a disappointing revival in these globally troubling times. In so doing, I remake a powerful case for Open Archaeology that is collaborative, participatory, public, and also feminist and activist.

To start then, what do we mean by the terms, 'collaborative', 'participatory', 'public' and 'democratisation'?

\section{Collaborative, participatory, public, and democratisation: a discussion of terms commonly used in the context of community archaeology}

Rather like the nuanced differences between the terms 'multidisciplinary', 'interdisciplinary', and 'transdisciplinary' (Nilsson Stutz, 2018, p. 49), terms such as 'collaborative', 'participatory', 'public', and 'democratisation' are used liberally in the titles of community archaeology journal articles but rarely unpacked. This is not necessarily because community archaeologists do not think deeply about what these terms mean (Atalay, 2012). On the contrary, efforts are being made to properly analyse collaborative archaeology approaches in such ways that evaluation based methodological frameworks may be shared (Guilfoyle \& 
Hogg, 2015). Equally, it may be precisely because communities are 'diverse, fragmented and complex' (González-Ruibal, et al., 2018, p. 508) that 'rigid definitions' (Thomas, 2014, pp. 24-25) of the terms 'collaborative', 'participatory', 'public', and 'democratisation' are avoided. However, in the interest of furthering our collective ability to critique and improve such approaches to the past, and in light of current sustained attacks upon collaborative archaeology (see Wylie, 2019 for an overview of criticism of collaborative archaeology since the 1990s), it would seem both timely and useful to examine these terms more closely. I start by engaging in a little etymological excavation!

\section{Collaborative and participatory}

The Oxford English Dictionary defines the adjective 'collaborative' as meaning 'produced by or involving two or more parties working together'. The word 'participatory' emerged in the English language from around the fifteenth century and comes from the verb 'to participate', defined as meaning 'to be involved; to take part'. 'Participate' derives from the Latin participat - or 'shared in', which comes from the verb participare - 'to take' - of which an archaic meaning is, 'to have or to possess something' ${ }^{3}$. The archaic Latinate root meaning of the word 'participate' - 'to possess something' - seems particularly apt in the context of community archaeology because, arguably, a primary reason for using participatory approaches is to redistribute ownership of the past and to hand back or reveal pasts which were (or continue to be) misappropriated, denied or hidden (for example, indigenous, Aboriginal, or working-class histories). To some extent, an implied anticipated outcome of collaborative and participatory archaeological work that at least some aspect of the past is repossessed by community participants (cf. Colwell, 2016).

While not without criticism (Supernant \& Warrick, 2014; see also, González-Ruibal, et al., 2018), collaborative approaches to the past are becoming 'the new norm' (Halperin, 2017, p. 291 ) - although the quality of such projects and degree to which they may be considered truly collaborative varies a great deal. To my mind, for a project to claim to be genuinely collaborative, it needs to be structured in such a way that each individual - or community group - involved is able to contribute their knowledge, skills, and experiences in ways which are meaningful to them (Kiddey, 2017a). Projects must adopt a transparent process which is open to scrutiny; the research agenda must be driven by questions reflective of the concerns of community stakeholders (Lidén \& Eriksson, 2013), take account of who has control of research funds and who decides how these are spent (Colwell, 2016). As Sonya Atalay has argued cogently, we must take account of diverse knowledge (Atalay, 2012) - and this includes the expert knowledge of archaeologists - to develop genuinely collaborative approaches to the past. In my view, it is transdisciplinarity which best encourages greater disciplinary literacy and allows people to speak and be heard across disciplinary, as well as cultural, borders (Nilsson Stutz, 2018). It is my contention that this approach is the most likely to foster meaningful, long-term relationships with individuals and communities, and contribute most helpfully to the ongoing project of decolonisation.

\footnotetext{
1 "collaborative, adj." OED Online. Oxford University Press, June 2019. Web. 3 August 2019.

2 "participate, adj. and n." OED Online. Oxford University Press, June 2019. Web. 3 August 2019.

3 "participate, v." OED Online. Oxford University Press, June 2019. Web. 3 August 2019.
} 
It is the deep level of engagement at every stage of the research process which can make collaborative projects so 'slow' (Carraher, 2019). It is also extremely time-consuming to do collaborative and participatory archaeology well! Institutions which deal with archaeology and cultural heritage - universities, museums, and community organisations - and funding bodies are increasingly beholden to 'fast capitalist' ideology which does not value time spent developing meaningful relationships and research designs with stakeholders ${ }^{4}$. Slow approaches to collaborative archaeology also require that all members of the team academics, professional archaeologists, non-expert stakeholders - are prepared to 'listen to and learn from one another, and...negotiate research agendas and interpretations' (Milek, 2018 , p. 37). This multi-perspectival, often multi-sited, horizontal approach to community archaeology is what makes it public (cf. Voss, 2016).

\section{Public}

The use of the word 'public', in the context of archaeology, has many meanings (Skeates, et al., 2012). Lorna-Jane Richardson and Jaime Almansa-Sánchez begin their useful discussion paper by defining public archaeology as:

'...both a disciplinary practice and a theoretical position, which can be exercised through the democratisation of archaeological communication, activity or administration, through communication with the public, involvement of the public or the preservation and administration of archaeological resources for public benefit by voluntary or statutory organisations...public archaeology is as much an activity as a theoretical concept, and operates in a wide variety of societal, social, and academic contexts. ' (Richardson \& Almansa-Sánchez, 2015, pp. 1-2)

The public - or 'the People' (González-Ruibal, et al., 2018, p. 508) - is a plurality of interest groups and individuals, with overlapping and sometimes competing motivations. It is people (who fall into different, entangled communities which are messy, contradictory, and conflictual) who lie at the heart of public archaeology, as they have done for some time (McGimsey, 1972). These people, as individuals and sometimes self-identified communities, pay for archaeology through their taxes (Zimmerman, 2018, p. 524); they are also visiting archaeological sites and engaging with cultural heritage in increasing numbers (Holtorf, 2007). To these numbers, we might add those who behave 'the wrong way, even those 'communities' whose views archaeologists typically abhor - racists, bigots, homophobes, Holocaust deniers and Far-Right sympathisers, for example. Such groups, however vile, cannot exist outside of 'the People'; indeed, they too have some rights, limited by law, to identify the heritage of their very distasteful views ${ }^{5}$. As a woman and an archaeologist dedicated for ten years to community-based participatory research (Kiddey, 2017, Kiddey, 2019), it is not because the ideologies of such execrable groups do not 'closely match the ethical-political expectation' (González-Ruibal, et al., 2018, pp. 508-509) of people like me that I do not work with right-wing sympathisers. It is because if I extended an invitation to, for example, members of the U.K. far-right group, the English Defence League, to work with

\footnotetext{
${ }^{4}$ Here, I would like to acknowledge a session at the Society of Historical Archaeology's annual conference in Boston, $9^{\text {th }}$ January 2020. The session was entitled 'Fast Capitalism/Slow Archaeology: subtitle and many of my fellow contributors drew on examples from their own work which made similar points to the one that I highlight here.

${ }^{5}$ Article 27.1a Universal Declaration of Human Rights states that 'everyone has the right to participate in cultural life'. However, Article 29.2 defines the limitations of such engagements. See https://www.un.org/en/universal-declaration-human-rights/
} 
me on documenting their heritage perspectives, they would surely decline on the basis that I am a woman who stands publicly and speaks out vociferously in solidarity with displaced people. Different interests require different types of public archaeologies (see Schadla-Hall, 1999, p. 150). I am motivated to highlight the inherent problems that face the world's 70.8 million displaced people ${ }^{6}$ and believe that there are good reasons why community archaeology can be instrumentalised to do so (see more, below). Someone else might want to use public archaeology to foreground the plight of hedge-fund managers or border guards. That is up to them. The field is open to everyone.

Archaeology that is public, then, is concerned with public interest in, attitudes to, and perceptions and uses of the past, issues which all relate closely to the use of public funds. To survive and potentially contribute intellectually to arguments for changing the capitalist system that grips the world in ever more threatening ways, archaeology must first demonstrate how it is of public benefit and why public funds should be used to pay for it. We have known this for some time (Fritz \& Plog, 1970, p. 412). For fifty years, archaeologists have been attempting to make their research more relevant to ever widening 'publics' through education and training, by providing opportunities for increasingly diverse populations to be involved in archaeological practice. In recent years, it has been argued that such involvement should not be limited to the passive consumption of archaeological knowledge, produced through research projects designed and undertaken solely by professional archaeologists. Rather that genuine public archaeology is that which involves meaningful inclusion at all stages of the research process (see, Isherwood, 2009, Pyburn, 2009, Atalay, 2012, Thomas, 2014, Kiddey, 2017a, Kiddey, 2017b) - and often 'in their own settings and on their own terms' (Ryzewski \& Cherry, 2012, p.322). Such approaches often usefully apply aspects of anarchy theory (for examples, see Graeber, 2004, Angelbeck \& Grier, 2012, Eddisford \& Morgan, 2017, Borck \& Sanger, 2017; see also, Dézsi \& Wurst, 2020), which typically advocates that to be genuinely public, archaeological work must be undertaken by the people, for the people (Fowles, 2010). Such approaches are frequently inherently creative and reflective of punk and DIY culture more broadly (Morgan, 2015). It is in this way, I suggest that community archaeology can seriously claim to be a mode for improved democratisation.

\section{Democratisation}

Democratisation is generally understood to mean the action by which something is characterised by social equality, made more egalitarian, made accessible to anyone ${ }^{7}$. In the context of archaeology, we might understand democratisation in two main ways: 1) the democratisation of involvement and participation in genuine archaeological work. That is, not tokenistic involvement but active engagement with all stages of the archaeological research process, from handling primary data to the dissemination of results; and 2) the democratisation of representation in the past, a concept bound-up closely with decolonialism and advances towards social justice more broadly (Hamilakis, 2018). I will take these two aspects in turn.

The desire to democratise involvement in the practical business of archaeology was a key driving force behind the development of community-archaeology as a specific model, which, in the U.K. at least can be seen to have a longer historical narrative than is often credited (Isherwood, 2009). An inexhaustive list of various examples of community archaeology's

\footnotetext{
${ }^{6} \mathrm{https}$ //www.unhcr.org/ph/figures-at-a-glance

7 "democratization, n." OED Online. Oxford University Press, June 2019. Web. 24 July 2019.
} 
efforts to democratise public participation in the past might include: i) the Survey and Landscape Archaeology on Monserrat (SLAM) project (2009 - ongoing), established as a direct response to damage caused to Monserrat's archaeology by volcanic activity (and which continues to threaten it); ii) the Council for British Archaeology's Community Archaeology Bursaries Project (2011-2015), developed by Cherida Plumb, which provided year-long work placements for 51 community archaeologists ${ }^{8}$ (CABP), and intended to educate those already working in the archaeological sector to facilitate and encourage greater participation in archaeology; iii) Dig Greater Manchester (2011-2016), a project which provided access to archaeology to over 1400 volunteers and 3400 school children, none of whom had ever been involved in archaeology before; iv) Heritage in Hospitals, a University College London project which took museum objects to the bedsides of hospital patients ${ }^{9}$, to better understand the impact of object-handling on well-being; and, iv) Unearthing Detroit, a collaboration between Wayne State University and community volunteers to re-excavate finds which were originally excavated during the 1960s-1980s and use data to improve and reinterpret the 'post-industrial' city. ${ }^{10}$ In the same spirit, and on the cusp of arrival at the time of writing this, the Museum of London Archaeology (MOLA) has announced three Collaborative Doctoral Partnership Awards (CDPs), in partnership with the U.K. funder the Arts and Humanities Research Council (AHRC), where one of the key themes to be explored is 'citizen science' - diversity and engagement, education, public programming, and evaluation of the Museum's own citizen science projects. To these efforts to improve democratisation, we must add the establishment of particular laws such as the Cultural Record Act in Australia (1987) and the Native American Graves Protection and Repatriation Act (NAGPRA) in the United States of America (1990). The arrival and application of such laws have enabled descendant communities and archaeologists to push for more equality in relation to the past (see, for example, Zimmerman, 1989).

Finally, over the past two decades, digital technological advancements have affected community archaeology and contributed (largely positively) to the ongoing democratisation of the past. From television programmes and the use of film (Piccini, 2007), to the creation of digitally simulated archaeological sites, and cyborg archaeologies which include 'avatars, monsters, and machines' (Morgan, 2019). Archaeologists now have the capacity to 3D-print replica archaeological objects in order to promote further inclusivity and interactivity in public archaeology (Means, 2015). In short, digital technologies have become part of the established suite of archaeological methodologies, helping to improve the ways in which data are recorded while enabling and aiding analyses, interpretation, and the cataloguing and wider dissemination of research findings. Such digital technologies frequently enable professional archaeologists 'to consistently and meaningfully engage broad audiences' (Jeffrey, 2015, p. 151). Although, some recent research has cautioned that internet archaeology can occasionally have the undesirable effect of reinforcing power imbalances (Taylor \& Gison, 2016), an important point but one upon which I do not have the space to expand here.

The second aspect concerns the democratisation of representation in the past. It is wellrehearsed that archaeology as a discipline first emerged as a leisure pursuit of wealthy, white men, which inevitably had a profound effect upon how the past was interpreted (Trigger, 2006). Archaeology and anthropology emerged as disciplines in conjunction with the

\footnotetext{
${ }^{8}$ See https://new.archaeologyuk.org/community-archaeology-bursaries-project

${ }^{9} \mathrm{https://www.ucl.ac.uk/culture/projects/heritage-hospitals}$

${ }^{10} \mathrm{https}$ ://unearthdetroit.wordpress.com
} 
expansion of European colonialism and within the post-Enlightenment rationalist intellectual context. Just as early anthropologists interpreted the people whom they met in cultural evolutionary terms, early archaeologists operating at around the same time saw only white, male ancestors in the archaeological record. Racism not only pervaded the historical present but was imposed upon the deep and historical past and flung at the future, through the stories that archaeologists and anthropologists told about the world. This is why I must disagree most strongly that archaeology is '...not an issue of representation and storytelling' (González-Ruibal, et al., 2018, p. 510). I think that is exactly what it is and precisely why it is so vital to consider carefully how and with whom we tell archaeology's stories.

The democratisation of representation in the past is not just about 'peopling' the past in more accurate ways. It is one of the most fundamental ways in which archaeology can genuinely contribute to contemporary political debate because, I contend, that archaeological data do not form a neat, unquestionable 'record' of past events. Rather, they provide us with 'evidence for particular social practices' (Barrett 1988:6, emphasis in original). Following such thinking, archaeology has become an active methodology for recording evidence of social conditions in the present, which offers the possibility of improving conditions in the future (Stottman, 2010). Community archaeology has the capacity to produce radical, translational data which can be actively mobilised to highlight social injustices in the past and call for changes in the present - for the future. Powerful and pernicious ideologies capitalism, patriarchy, racism, homophobia - thrive on attempting to naturalise things as they are by insisting that 'things have ever been thus'. However, as community archaeologists, we have the power to facilitate diverse knowledge groups which can disrupt and counter ideologies about racism (Shackel, 2007, Battle-Baptiste, 2016 [2011]), class (McGuire, 2008), gender (Conkey \& Spector, 1984), heteronormativity (Blackmore 2011), and migration (Soto, 2016). This work is not done by offering multiple multicultural views of the past which are little more than a smörgåsbord of relative choice. Rather, to paraphrase Yannis Hamilakis, by identifying and locating material evidence of the multiple ways in which humans, plants, and animals have cohabited the Earth, across time (cf. Hamilakis, 2018, p. 518-519; González-Ruibal, 2018, p. 15 also calls for 'fuzzy' chronologies). Advocating 'new' animism, Ewa Domanska argues that it may yet be desirable to see humans and nonhumans as equally 'alive'. As Domanska puts it:

'... animism can be seen as a kind of radical ontology and epistemology, functioning as an antithesis of modern science as it effectively offers a critique of Western rationality and its mechanistic worldview, while helping to reconceptualise relations between nature and culture, humans and non-humans, the living and the dead, the organic and the inorganic...' (Domanska, 2018, p. 23).

At the heart of these multitemporal and multispecies approaches is the idea of consensus, (familiar to anarchism) as a useful way to think about relationships between people, nonpeople, things and places - such entanglements encourage critique of otherwise humancentred understandings of the world (Alberti, 2016, Fowler, 2016). By demonstrating contemporary, historical and pre-historical alternatives to capitalism, patriarchy, segregation, and oppression, the future is potentiallt liberated from the strangleholds of much of the political and economic present. Contrary to one of the favourite lines of Margaret Thatcher (the late Prime Minister of the United Kingdom), 'There Is No Alternative (TINA)' (Flanders, 2013; see also, Dézsi \& Wurst, 2020) very many alternatives to climate chaos and seemingly endless violence and destruction are rendered possible. This leads me to how 
community archaeology - with added feminism - may be considered a viable form of social activism.

\section{Community archaeology through a feminist lens: a powerful form of social activism}

As community archaeologists, we can use methods of public engagement which are genuinely collaborative and participatory to produce 'braided knowledge' - not multivocality but knowledge which 'intertwines with archaeological data' (Atalay, 2012, p. 27). Such knowledge may be translated and applied in ways which explicitly seek positive social and political change (cf. Zimmerman, et al., 2010). Indeed, for philosopher of science, Helen Longino (2002, quoted in Wylie, 2007), only when diverse critical perspectives are brought to bear on objects of study and upheld can a research community be justified in calling their results 'knowledge' (for a detailed discussion of the social nature of objectivity according to Longino, see Eigi, 2015). This concern with cognition and objectivity in the ideology of science and its practice has long been a specific concern for feminist scholars (see Spivak's 1988 postcolonial critique; also, Haraway, 1988, Harding, 1991). Objectivity is not obtained through a self-imposed claim to neutrality but '.... accountability for the interests that unavoidably inform inquiry, embodied in community mechanisms of transformative criticism (Longino, 2000, p. 71-74, quoted in Wylie 2007, p. 212). I want to suggest here that one answer to current calls for archaeology to go back to the roots of politics, and for it to become more provocative, is to embrace a 'reclaimed and reframed' form of feminism (Moraes \& Sahasranaman, 2018). Defining attributes of feminism include its commitment to nonexploitative practices of knowledge production and dedication to the democratisation of science (Longino, 2002). Indeed, a feminist perspective is most useful not least because it '...leads to consideration of other forms of difference, including race, ethnicity, class, sexuality and age...' (Engelstad, 2007, p. 218), which help to drive collaborative archaeology forwards in such ways that it is becoming an explicit form of social activism (Little \& Zimmerman, 2010, Stottman, 2010).

Drawing on my own experience - woman, community archaeologist, early career academic I want to make the case for contextualising collaborative archaeology within the context of a form of feminism redesigned for our sadly 'pussy-grabbing' ${ }^{11}$ times. As a British woman, drawing on personal experience, this section is somewhat unavoidaby British in tone and references. My intention is not to provide mere anecdote but to illustrate points of wider, global relevance in the context of present day feminist theory. Indeed, as Alison Wylie has previously argued:

'Gendered experience and self-understanding is a critical resource for feminist researchers in understanding where the limitations of extant research traditions lie, in framing research questions, in expanding the repetoire of interpretive or explanatory hypotheses, and in adjudicating the plausiblity of descriptive and analytic constructs - but it is alwavs open to critical scrutiny.' (Wylie, 2007, p. 212, emphasis added).

For the lucky few, among whom I count myself, women continue to experience patriarchal oppression as losing out on jobs, being paid less than their male counter-parts, being

${ }^{11} \mathrm{https}: / / w w w . t h e g u a r d i a n . c o m / u s-n e w s / 2016 /$ oct/07/donald-trump-leaked-recording-women 
patronised, 'man-splained' to, receiving abuse on buses ${ }^{12}$, in their homes, in the street, and still expected to undertake the lion's share of domestic tasks ${ }^{13}$. For less lucky women, patriarchal oppression comes in the form of domestic violence, coercive control, serious mental and emotional abuse, rape, and death (WHO, 2013).

Feminism, as a theoretical concept, has suffered some knocks in my lifetime. I was born in the United Kingdom in 1978. The first time I became aware of feminism was when my mother took my younger brothers and me to the protest camp at Greenham Common, in 1984, to show support for the women who demonstrated there (see Marshall, et al., 2009 for an archaeological discussion of the protests at Greenham). I was too young to understand the political nuances but I distinctly remember our mother telling my brothers and me about the threats posed by nuclear war, why women were protesting, and what made Greenham different from other protest sites, as we drove there in the car. Once there, I recall a powerful sense of women of all sorts and sizes - in camps, and vans, with and without children, women cooking, making, engineering, talking, kissing. It was a formative experience for a little girl.

Fast-forward to the 1990s. I was a teenager living in the U.K.. Second-Wave feminism was receiving harsh backlash from 'Brit-pop' associated 'lad-culture'. A peculiarly British subculture, 'lad-culture' emerged in the early 1990s and is best summarised as an anti-illectual movement which espoused rabid sexism, drinking, and violence (Gill, 2003). A disappointingly large number of young women at that time, myself included for some years, felt too uncomfortable to identify as 'feminist', largely due to the strong prevalence of the homophobic sterotypical image of the 1970 s feminist as a man-hating lesbian ${ }^{14}$. It is indicative of how bad the situation was that, on entering university for the first time in 1997, The Spice Girls were heralded new-wave feminists! Instead, people spoke of 'postfeminism' (Gamble, 2006). Lad-culture told women that we no longer needed feminism because we already had equality. We could become educated, get good jobs, use contraception, choose not to be married, buy property, report domestic violence - what was the point of feminism any longer? Oh, but we had also to drink pints, use crude language, and show our tits in the pub ('it's just banter, after all!'). Somehow simultaneously, we were to remain demure, untainted, unfunny, and willing to settle down, to become wives and have babies. For all the privileges that come with growing up in the U.K - and there are many reasons why my own experience of patriarchy is incomparable to that of other women in the world (Franklin, 2001) - it was a hideous place to be a young woman in the 1990s and this is why feminism mattered then and why it still matters today (cf. Engelstad, 1991, Hays-Gilpin, 2000, Dicker \& Piepmeier, 2003, Lønna, 2004, Moraes \& Sahasranaman, 2018).

While I accept that identity politics are problematic and often serve to shore up imagined divisions between social groups, we cannot simply choose to escape the socio-political effects of identities which the current order ascribes us - women are treated differently from men; racism, homophobia, and elitism exist (cf. González-Ruibal, et al., 2018, p. 513). Identities and narratives are always physically embodied and they leave distinct material, tangible legacies which is justification for their ongoing investigation through collaborative, participatory, community-based archaeological means (cf. Alcoff, 2006). After Donna

${ }_{13}^{12}$ https://www.bbc.co.uk/news/uk-england-london-49119947

https://www.ons.gov.uk/employmentandlabourmarket/peopleinwork/earningsandworkinghours/articles/womens houldertheresponsibilityofunpaidwork/2016-11-10

${ }^{14}$ Even scholars of gender in archaeology found it impossible to support feminism at this time, citing it as just one

'...amongst other marginal or minority [voices], one that is relevant only to feminists' (Sørensen, 2000, p. 36). 
Haraway, I suggest that a feminist perspective is particularly useful to community archaeology because it concerns a '...practice of objectivity that privileges contestation, deconstruction... webbed connections and hope for transfomation of systems of knowledge...' (Haraway, 1988, p. 585). In this way, a feminist lens can bring to bear on the material and visual cultural remains of the multi-temporal past a critical and reflexive perspective on how - and with whom - we create and pass on knowledge about the world. This task requires us to work together, to draw on diverse knowledge systems using collaborative methodologies. The job is too important to be left only to those few archaelogists privileged enough to occupy professional positions which release them from 'the anxieties of practical usefulnessness, economic performance, immediate applicability and popular acceptance' (González-Ruibal, et al., 2018, p. 513) - certainly, if those professional archaeologists are all white men! Or, indeed, if those professional archaeologists are all white people generally (Franklin, 2001, Battle-Baptiste, 2016 [2011]). As Whitney Battle-Baptiste argued eloquently during her keynote speech at the Society of Historical Archaeology's annual conference in Boston, there have been black and indigenous scholars writing on archaeology for many years but they remain sorely overlooked and under-cited. One of the ways in which archaeology can instantly become more open and representative is by those of us privileged to occupy professional positions of some influence making conscious and sustanined effort to read (and set for our students to read) existing published work by our black and indigenous peers, and to cite it properly ${ }^{15}$.

Having contextualised what I understand by the commonly used terms 'collaborative', 'participatory', 'public' and 'democratisation', and suggested how a specifically feminist lens strengthens the socially activist capabilities of community archaeology, I turn now to a broader discussion of relevant issues. Why is it that researchers are often reluctant to report frictions encountered during collaborative heritage work? How can we, as academics, define the limits of inclusivity and openness in the name of democracy? Which methods and strategies are more likely to lead to a beneficial outcome for archaeologists and community partners? In the following section of the article, I draw on experiences encountered over ten years as an academic and community archaeologist, to reflect on these questions.

\section{The problem with community: conflicts and frictions}

Community is a tricky concept and a difficult word to define. Despite the rise and rise of community archaeology projects in Canada (Lea, 2016) the United States (Cipolla \& Quinn, 2016), Australia (Greer, 2014), across Europe (Diaz-Andreu \& Ruiz, 2017), and parts of Africa (Mokoena, 2017), very few archaeologists work with a single 'community'. Rather, as archaeologists, we work with individuals who overlap various communities, for example, linked through locale, family, school, ethnicity, religious or cultural background.

Archaeologists often fail to acknowledge this (although, see Pyburn, 2011). Communities are also often misconstrued as being inherently 'good' but they are not always safe, not always desirable. For those on the outside of a real or 'imagined' community (Anderson, 1983), it can lead to feelings of exclusion and insecurity (Baumann, 2001) - it can itself be a 'contact zone' (Clifford 1997). Community is an indisputably complex concept which brings with it a host of, often competing, politics and motivations (Crooke, 2010) - and yet as archaeologists

\footnotetext{
${ }^{15}$ Whitney Battle-Baptiste's keynote plenary to the Society of Historical Archaeology Annual Conference, on the theme 'Revolution', Wednesday $8^{\text {th }}$ January 2020, Boston, MA.
} 
who work with communities, in communities, creating communities, we have yet to find a better word. 'Public', as we saw above, is just as vague and difficult to define.

In her useful theorisation of the concept of 'community', Anna Agbe-Davies traces the scholarly use of the word to the seventeenth century, used in attempts to distinguish small social relations from states (Agbe-Davies, 2010, pp. 375-6). If we are clear that communities usually overlap (spatially and temporally) then the notion of community, despite its irregularity, can still be useful. Indeed, Agbe-Davies goes on to stress that the 'slipperiness and imprecision' (Agbe-Davies, 2010, p. 384) of the concept is precisely what makes it useful in the context of collaborative heritage work because it encompasses many types of social structures and interests (Creed, 2006, p 4, quoted in Agbe-Davies, 2010) - which allow for change and difference. However, despite the ethical imperative to do so, it is probably the 'small 'p" politics present in any community that is to blame for the reluctance which most researchers feel about openly acknowledging frictions and conflicts which arise during community-based participatory research (Pyburn, 2009, pp. 165-166).

Despite the cliché that failure in academia is a gift from which much can be learned ${ }^{16}$, academic researchers fear that to admit negative findings or to openly share conflicts or frictions encountered during community projects would severely jeopardise their future job prospects. I have personal experience of this. Towards the end of my doctoral work I told a senior colleague that I was considering publishing a paper on the plentiful pitfalls and problems which I had encountered during collaborative archaeological fieldwork with contemporary homeless colleagues (cf. Kiddey, 2014). My senior colleague shot me a look and, with a furrowed brow, said, 'That's a terrible idea! You should focus on telling people what you got right! No one will fund you for failure.' With so many, even relatively wellestablished, academics just about surviving in precarious, non-tenured positions, who would choose to take the added risk of publicly acknowledging the ways in which they failed to get on with the community with which they were working, the ways in which their work flopped? In my case, I recast the problems which I had encountered during fieldwork as 'challenges', and even then, kept the discussion to just four pages in my monograph, only publishing once my doctorate was safely in hand (Kiddey, 2017a, pp. 62-68).

A further criticism often levied at community-based collaborative approaches to the past is that the portrayal of community partners is most usually 'overwhelmingly sunny' (Halperin, 2017, p. 291) or 'celebrated' (González-Ruibal, et al., 2018, p. 509). Whether collaborative community archaeology projects are emic, etic, or they involve the creation of a community (for examples, see Schmidt, 2017, Kiddey, 2017b) - a huge amount of time is spent before any archaeological work is undertaken developing trust between the researcher and the rest of the team. It takes weeks if not months and sometimes years (see Knecht, 2014) to negotiate, discuss, and decide how best to undertake the work, the planned outputs, dissemination strategies, and future stewardship (Colwell-Chanthaphonh \& Ferguson, 2004). If, at the end of this process, the researcher published a host of negative experiences it would, in my view, be a simple act of betrayal. Investing such a lot of time in developing genuine relationships with community partners, one cannot help but form friendships - birthdays are celebrated, babies are born, people die - and it would be deeply unethical for a researcher to befriend people, persuade them to trust them, and then publicly air disputes. Conflict may have arisen through the deeds or actions of just one or two individuals but to publish such details could

\footnotetext{
${ }^{16} \mathrm{https}$ ://www.theguardian.com/higher-education-network/2015/nov/04/academics-you-are-going-to-fail-solearn-how-to-do-it-better
} 
affect how an entire community or ethnic/religious/social group was then viewed and treated. In such a hypothetical situation, the researcher would receive short shrift if they tried to say that they had betrayed their collaborators for the good of widening academic knowledge. As academics, we do not publish the multitude of annoying/offensive/unethical things which our academic colleagues do (or do not do), so why should we 'name and shame' our communitybased colleagues? This is not to suggest that the difficult, conflictual aspects of community based participatory research - and I wholly acknowledge that there are some - can never be known. Rather it illustrates why it is so essential for us to further develop critical strategies for deciding how best to highlight, tackle, and where possible, co-publish articles on such issues with the communities with which we work (see, Crea, et al., 2014, for an example of a co-authored peer-reviewed article. See also, Kiddey, et al., forthcoming). In this sense, identifying issues and frictions together is one of the ways in which community archaeology can be genuinely redemptive and contribute meaningfully to conflict resolution - in other words, a form of social activism.

\section{Methods and strategies for beneficial outcomes}

I advocate Open Archaeology that is genuinely:

'... a way of producing new knowledge about the past that does not privilege one investigator over another but gives everyone who is interested and wants to participate an opportunity to do so.' (Milek, 2018, p. 37)

Open and Collaborative Archaeology is, to some extent, already producing new knowledge because the inductive nature of Open Archaeology means that outcomes can rarely be predicted. Rather, only by doing the work together - archaeologists and non-expert community members actively collaborating during all stages of the research process - do outcomes become known. In this way, Open Archaeology is also always inherently 'slow', often employing ethnographic methods which are notoriously difficult to quantify. This makes Open Archaeology a useful tool with which archaeologists can resist 'fast capitalist' ideology and its impact upon our understanding of the past and our thoughts about the future. However, to fully achieve what Karen Milek calls for (see quote above), I suggest that there are several other strategies which archaeologists might find useful.

First, I contend that archaeologists must acknowledge that despite our intellectual dislike of capitalism - and I share it wholeheartedly - we currently live under its thumb and the vast proportion of archaeological work is paid for using public funds. We must be explicit about what archaeology can offer tax-payers or they will reject archaeology in favour of more traditional health and education services. Therefore, we might first clearly demonstrate the ways in which archaeology can be useful in developing and sustaining strong criticism of capitalism and producing alternative world views! Archaeology - as a fun, engaging method for learning with diverse communities and braided knowledge - can show itself to be 'earning its keep' (Buchli, 2007) by promoting the multiple ways in which the study of the past contributes to our understanding of human-environmental interactions, which can inform better sustainability practices (Halperin, 2017).

Second, I suggest that by encouraging trans - as opposed to inter - disciplinary literacy across the sector and seeking diverse disciplinary collaborations, we might 'deepen our understanding of the past and strengthen its broader relevance in the present' (Nilsson Stutz, 2018, p. 52). Third, I contend that by widening the network of places (and countries) where 
we do community archaeology we might further demystify the discipline and encourage still broader participation. One way to do this is to improve the portability of archaeological science (Milek, 2018, pp. 43-44) so that more people become familiar with archaeological tools and methods and are trained to analyse and critique data. This paves the way for diverse, genuine, long-term communities to develop around particular archaeological sites or landscapes - Çatalhöyük is perhaps one of the best examples of this happening (Atalay, 2010). As Elizabeth Crooke points out, communities may be judged successful when they are so embedded that they are perceived to be indisputable - in these instances, they become:

'... a galvanising force and a legitimising factor, which can justify actions and interests of the group. This is when the formation of community can have political force...' (Crooke, 2010, p. 19).

Fourth, I suggest that it would be helpful for archaeologists to adopt approaches which prioritise "not the pursuit of power, but the promotion of horizontality that solicits changes stimulated from below' (Domanska, 2018, p. 22). As colleagues have argued previously, this is perhaps best achieved by giving careful consideration to the balance of power within archaeology, in paying attention to who controls the research agenda (Atalay, 2012), who decideds how to spend public funds (Colwell, 2016), and who is responsible for the publication of findings. To achieve such horizontality, I strongly advocate 'slow' archaeology (Carraher, 2019) because it prioritises genuine community involvement in every stage of the research process above all other measures of success. Related to this is my fifth point, the need for archaeologists to pay closer attention to the ongoing legacy of their work by building public engagement and popular events into the original research design. Archaeologists are often willing to trivialise the significance of what we do in order to attract media attention and have impact (Zimmerman, 2018, p. 524). However, if we think of the issue of how we will translate our research findings in ways which will engage non-academic audiences as being of equal importance to publishing in high-ranking journals, we can break free of the confines of academia, stimulate wider discussion, and show archaeology to be highly relevant to present-day concerns. In respecting the value of and making the time to write for more accessible platforms such as The Conversation ${ }^{17}$ or Sapiens ${ }^{18}$, we can make meaningful links with policy makers and people in positions of local, national, and international influence. The sixth point that I would like to make is that community archaeologists need to further develop robust qualitative evaluation models and get better at sharing best practice (Guilfoyle \& Hogg, 2015). In these ways, community archaeology really can change the world! (Stottman, 2010).

\section{Conclusion}

Together with Ewa Domanska (Domanska, 2018, p. 25) and others, I agree with Tim Flohr Sørensen that the 'New New Archaeology' (Sørensen, 2017, p. 101) - or a return to hypothesis-testing, scientific approach in archaeology - is deeply troubling because it impoverishes social interpretation and devalues or marginalises completely all knowledge indigenous, Aboriginal, community-based - which is not quantifiable (González-Ruibal, 2018, p. 11, Nilsson Stutz, 2018, p. 51; see also Ion, 2017). In this regard, I find the concept of the capitalocene (Moore, 2016) more useful than the anthropocene because the devastating effects of the latter are largely down to the actions - and inaction - of predominantly white,

\footnotetext{
$17 \mathrm{https}: / /$ theconversation.com/uk

18 https://www.sapiens.org/columns/
} 
Western men. Alfredo González-Ruibal is quite right to point out how unfair and incorrect it is to lay the burden of our most pressing global issue at the feet of all humans, across time and place (González-Ruibal, 2018, p. 13). Do we want to live in a world where only those aspects of the past which are marketable are valued? Those of us who understand the usefulness of the humanities and the intrinsic value of social scientific interpretation must push back against the current hegemony of the new scientific approach to the past, I argue. We must defend space for that which cannot be quantified, measured, packaged, and sold. If we do not defend qualitative and interpretive approaches to the past, we risk losing completely ways of knowing which may yet provide essential lessons about alternative temporalities and less-destructive futures (Péttursdòttir, 2017). However, what is the point of protecting such diverse forms of knowledge - black, indigenous, Aboriginal, or workingclass, for example - if we then close off opportunities for collaborations with the very communities from which they emanate? What is the point in calling for a return to '.... simplistic (and condescending) notion that archaeologists have the right to dictate to others how the past is to be understood...'? (Bernbeck \& Pollock, 2018, p. 517).

The challenge to archaeologists, I contend, is to 'use the diverse knowledge of us all' (Atalay, 2012) to harness cultural heritage in sufficiently robust ways that our findings may be used to peacefully but strongly counter the zealous dogma of racists, fascists, and capitalists. As Ewa Domanska's 'prefigurative' approach to knowledge building proposes, rather than marginalising communities - descendant, Indigenous, homeless, working-class, or any others - we need to acknowledge that the humanities and social sciences contribute just one constitutive part of knowledge - we cannot solve the problems of the world without listening to and valuing other ways of knowing (Domanska, 2018, p. 23). Homeless people (or any other complex, diverse, fragmented social group) are not rendered the 'the perfect subject' (Fowles, 2016; cf. González-Ruibal, et al., 2018, p. 508) if we are careful to ensure that our methods of engagement are always open to scrutiny. In fact, the exact opposite is true because it is through such Open Archaeology that previously silenced communities are given voice. As Joan Gero pointed out, what archaeology needs is not certitude but more complexity, more ambiguity, less reduction, less impulse to seek closure - we should:

'...resist imposing meanings on our subjects: modern, disciplinary, uniform and universalist, and move instead towards honouring (instead of erasing) the evidence that will not yield to closure' (Gero, 2007, p. 314)

We need to adopt and refine methods for opening up conversation between archaeologists and non-archaeologists. We need to cross borders - intellectual, disciplinary, political, and geographic -and be better at listening to what others are saying, better prepared to respond to uncertainties and conflict by remaining open to changing our current understanding of the order of things. Such '....issues of ambiguity are also feminist issues because they are issues of power' (Gero, 2007, p. 322, emphasis added). We need to extend our care for others and increase our capacity to nurture - these are attributes often associated philosophically with the feminine (Noddings, 1984). For community archaeology to further develop its evident potential for social activism, I suggest that it needs to more fully embrace feminism. Finally, I would like to conclude with a serious call to all archaeologists to 'check their privileges' ${ }^{19}$ check their whiteness, their able-bodied-ness, their positions of power and authority, their

\footnotetext{
${ }^{19}$ I would like to acknowledge my friend and colleague Dr Whitney Battle-Baptiste with whom I was honoured to share a platform for panel discussion at CHAT 2018, at Aarhus Universitet, Denmark. The conversations that Whitney and I enjoyed during the panel and informally at the conference helped to shape many of the thoughts that are expressed in this paper.
} 
influence, their security, their hetero-normativity, and their maleness - before they suggest that anyone has the right to dictate to others how the past should be understood. The past is Open to everyone.

\section{Bibliography}

Agbe-Davies, A. S., 2010. Concepts of community in the pursuit of an inclusive archaeology. International Journal of Heritage Studies, 16(6), pp. 373-389.

Alberti, B., 2016. "Archaeologies of Ontology". Annual Review of Anthropology, Volume 45, pp. 163-179.

Alcoff, L. M., 2006. Visible Identities: Race, gender, and the self. Oxford: Oxford University Press. Anderson, B., 1983. Imagined Communities. London: Verso.

Angelbeck, B. \& Grier, C., 2012. Anarchism and the Archaeology of Anarchic Societies: Resistance to Centralisation in the Coast Salish Region of the Northwest Coast. Current Anthropology, 53(5), pp. 547-587.

Atalay, S., 2010. 'We don't talk about Çatalhöyük, we live it': sustainable archaeological practice through community-based participatory research. World Archaeology, 42(3), pp. 418-429.

Atalay, S., 2012. Community-Based Archaeology: Research with, by, and for Indigenous and Local Communities. Berkley and Los Angeles, California: University of California Press.

Barrett, J. C., 1988. Fields of Discourse: reconstituting a social archaeology.. Critique of Anthropology, 7(3), pp. 5-16.

Battle-Baptiste, W., 2016 [2011]. Black Feminist Archaeology. Abingdon: Routledge.

Baumann, Z., 2001. Community: seeking safety in an insecure world. Cambridge: Polity Press.

Bernbeck, R. \& Pollock, S., 2018. Archaeology's People. Antiquity, 92(362), pp. 516-517.

Blackmore, C., 2011. How to queer the past without sex: Queer Theory, Feminisms, and the Archaeology of Identity. Archaeologies: Journal of the World Archaeological Congress, 7(1), pp. 7596.

Borck, L. \& Sanger, M. C., 2017. An Introduction to Anarchism in Archaeology. The Society of American Archaeology Archaeological Record, 17(1), pp. 9-16.

Buchli, V., 2007. Opinion. Conservation Bulletin, 56(14).

Buchli, V. \& Lucas, G., 2001. Archaeologies of the Contemporary Past. London: Routledge. Carraher, W., 2019. Slow Archaeology, Punk Archaeology, and the 'Archaeology of Care'. European Journal of Archaeology, pp. 1-14.

Cipolla, C. N. \& Quinn, J., 2016. Field School Archaeology the Mohegan Way: Reflections on Twenty Years of Community-Based Research and Teaching,. Journal of Community Archaeology and Heritage, 3(2), pp. 118-134.

Clifford, J., 1997. Routes: travel and translation in the late twentieth century. Cambridge, MA: Harvard University Press.

Colwell, C., 2016. Collaborative Archaeologies and Descendant Communities. Annual Review of Anthropology, Volume 45, pp. 113-127.

Colwell-Chanthaphonh, C. \& Ferguson, T. J., 2004. Virtue ethics and the practice of history: native Americans and archaeologists along the San Pedro Valley of Arizona. Journal of Social Archaeology, 4(1), pp. 5-27.

Conkey, M. \& Spector, J., 1984. Archaeology and the study of gender. Advances in archaeological method and theory, Volume 7, pp. 1-38.

Crea, G. et al., 2014. Turbo Island, Bristol: excavating a contemporary homeless place. Post-medieval Archaeology,, 48(1), pp. 133-150.

Crooke, E., 2010. The Politics of Community Heritage: motivations, authority, and control.

International Journal of Heritage Studies, 16(1-2), pp. 16-29.

Dé Leon, J., 2015. The Land of Open Graves: living and dying on the migrant trail. Oakland:

University of California Press.

Desilvey, C., 2017. Curated Decay: Heritage Beyond Saving. Minneapolis: University of Minnesota Press. 
Dézsi, A. \& Wurst, L., 2020. Theorizing Capitalism's Cracks. Boston: Paper presented at the Society of Historical Archaeology conference, 2020.

Diaz-Andreu, M. \& Ruiz, A., 2017. Interacting with Heritage: Social Inclusion and Archaeology in Barcelona. Journal of Community Archaeology and Heritage, 4(1), pp. 53-68.

Dicker, R. \& Piepmeier, A., 2003. Catching a Wave: reclaiming feminism for the 21st century.

Boston: Northeastern University Press.

Domanska, E., 2018. Is This Stone Alive? Prefiguring the Future Role of Archaeology. Norwegian Archaeological Review, 51(1-2), pp. 22-35.

Eddisford, D. \& Morgan, C., 2017. Single Context Archaeology as Anarchist Praxis. Journal of Contemporary Archaeology, 5(2), pp. 117-206.

Eigi, J., 2015. On the social nature of objectivity: Helen Longino and Justin Biddle. Theoria, 30(3), pp. 449-463.

Engelstad, E., 1991. Images of power and contradiction: feminist theory and post-processual archaeology. Antiquity, Volume 65, pp. 502-514.

Engelstad, E., 2007. Much More than Gender. Journal of Archaeological Method and Theory, Volume 14, pp. 217-234.

Flanders, L., 2013. At Thatcher's funerl, Bury TINA Too. [Online]

Available at: https://www.thenation.com/article/thatchers-funeral-bury-tina-too/

[Accessed August 2019].

Fowler, C., 2016. Relational Personhood Revisited. Cambridge Archaeological Journal, 26(3), pp.

397-412.

Fowles, S., 2010. A People's History of the American Southwest. In: S. Alt, ed. Ancient Complexities: New Perspectives in Pre-Columbian North America. Provo: University of Utah, pp. 183-204.

Fowles, S., 2016. The Perfect Subject. Journal of Material Culture, Volume 21, pp. 9-27.

Franklin, M., 2001. A Black-feminist inspired archaeology?. Journal of Social Archaeology, 1(1), pp. 108-125.

Fritz, J. M. \& Plog, F. T., 1970. The Nature of Archaeological Explanation. American Antiquity, 35(4), pp. 405-12.

Gamble, S., 2006. Postfeminism. In: S. Gamble, ed. The Routledge Guide to Feminism and

Postfeminism. London: Routledge, pp. 36-45.

Gero, J., 2007. Honouring ambiguity/problematizing certitude. Journal of Archaeological Method and Theory, Volume 14, pp. 311-327.

Gill, R., 2003. Power and the production of subjects: a genealogy of the New Man and the New Lad.

The Sociological Review, 51(1), pp. 34-56.

González-Ruibal, A., 2018. Beyond the Anthropocene: Defining the Age of Destruction. Norwegian

Archaeological Review, 51(1-2), pp. 10-21.

González-Ruibal, A., 2018. Welcome Conflict. Archaeology and the Return of the Political.

Barcelona: s.n.

González-Ruibal, A., Alonzo_González, P. \& Criado-Boado, F., 2018. Against Reactionary

Populism: towards a new public archaeology. Antiquity, 92(362), pp. 507-515.

Graeber, D., 2004. Fragments of an Anarchist Anthropology. Chicago: Prickly Paradigm Press.

Greer, S., 2014. The Janus View: Reflections, Relationships and a Community-Based Approach to

Indigenous Archaeology and Heritage in Northern Australia. Journal of Community Archaeology and Heritage, 1(1), pp. 56-68.

Guilfoyle, D. R. \& Hogg, E. A., 2015. Towards an Evaluation-Based Framework of Collaborative Archaeology. Advances in Archaeological Practice, 3(2), pp. 107-123.

Halperin, C. T., 2017. The Year in Review: Anthropological Archaeology in 2016: Cooperation and Collaborations in Archaeological Research and Practice. American Anthropologist, 119(2), pp. 284297.

Hamilakis, Y., 2018. Decolonial archaeology as social justice. Antiquity, 93(362), pp. 518-520. Haraway, D., 1988. Situated knowledges: The science question in feminism and the privilege of partial perspective. Feminist Studies, Volume 14, pp. 575-599.

Harding, S., 1991. Whose science? Whose knowledge? Thinking from women's lives. Ithaca: Cornell University Press. 
Hays-Gilpin, K., 2000. Feminist scholarship in archaeology. Annals of the American Academy of Political and Social Science, Volume 571, pp. 89-106.

Holtorf, C., 2007. Archaeology is a Brand! The meaning of archaeology in contemporary popular culture. Walnut Creek, CA: Left Coast Press.

Ion, A., 2017. How interdisciplinary is interdisciplinarity? Revisiting the impact of aDNA research for the archaeology of human remains. Current Swedish Archaeology, Volume 25, pp. 177-198.

Isherwood, R., 2009. Community Archaeology: A study of the conceptual, political and practical issues surrounding community archaeology in the United Kingdom today, unpublished PhD thesis, University of Manchester, U.K.. [Online]

Available at: https://ethos.bl.uk/OrderDetails.do?uin=uk.bl.ethos.498943

[Accessed 3 July 2019].

Jeffrey, S., 2015. Challenging Heritage Visualisation: Beauty, Aura and Democratisation. Open Archaeology, Volume 1, pp. 144-152.

Kiddey, R., 2014. Homeless Heritage: collaborative social archaeology as therapeutic practice.

[Online]

Available at: http://etheses.whiterose.ac.uk/6262/

[Accessed 4th July 2019].

Kiddey, R., 2017a. Homeless Heritage: social archaeology as therapeutic practice. Oxford: Oxford University Press.

Kiddey, R., 2017b. From the Ground Up: cultural heritage practices as tools for empowerment in the Homeless Heritage project. International Journal of Heritage Studies, 24(7), pp. 694-708.

Kiddey, R., 2019. Reluctant Refuge:. Journal of Refugee Studies.

Kiddey, R., Murrani, S. \& Bellinger, A., forthcoming. Different Ways of Doing: reflections on a knowledge exchange fellowship.

Knecht, R., 2014. Nunalleq: rescuing an Eskimo village from the sea. British Archaeology, Volume 136.

Lønna, E., 2004. Waves in the History of Feminism. In: H. R. Christiansen, B. Halsaa \& A. Saarinen, eds. Crossing Borders: re-mapping women's movements at the turn of the 21st century. Odense:

University Press of Southern Denmark, pp. 41-58.

Lea, J., 2016. Pioneer Villages in Ontario, Canada: Communities of Heritage. Journal of Community Archaeology and Heritage, 3(3), pp. 165-182.

Lidén, K. \& Eriksson, G., 2013. Archaeology vs. archaeological science: do we have a case?. Current Swedish Archaeology, Volume 21, pp. 11-20.

Little, B. J. \& Zimmerman, L. J., 2010. In the public interest: creating a more activist, civically engaged archaeology. In: W. Ashmore, D. Lippert \& B. Mills, eds. Voices in American Archaeology. Washington, D.C.: Society for American Archaeology, pp. 131-159.

Longino, H. E., 2002. The Fate of Knowledge. Princeton, N.J.: Princeton University Press.

Marshall, Y., Roseneil, S. \& Armstrong, K., 2009. Situating the Greenham Archaeology: An

Autoethnography of a Feminist Project. Public Archaeology, 8(2), pp. 225-245.

McAnany, P. A. \& Rowe, S. M., 2015. Re-visiting the field: Collaborative archaeology as paradigm shift. Journal of Field Archaeology, 40(5), pp. 499-507.

McGimsey, C. R., 1972. Public Archaeology. New York: Seminar Press.

McGuire, R. H., 2008. Archaeology as Political Action. London: University of California Press.

Means, B. K., 2015. Promoting a More Interactive Public Archaeology: Archaeological Visualization and Reflexivity Through Virtual Artifact Curation. Advances in Archaeological , 3(3), pp. 235-248.

Milek, K., 2018. Transdisciplinary Archaeology and the Future of Archaeological Practice: Citizen Science, Portable Science, Ethical Science. Norwegian Archaeological Review, 51(1-2), pp. 36-47. Mokoena, N., 2017. Community involvement and heritage management in rural South Africa. Journal of Community Archaeology and Heritage, 4(3), pp. 189-202.

Moore, J. W., 2016. The Rise of Cheap Nature. In: J. W. Moore, ed. Anthropocene or Capitalocene?. Oakland: PM Press, pp. 78-115.

Moraes, E. \& Sahasranaman, V., 2018. Reclaim, resist, reframe: reimagining the feminist movement in the 2010s. Gender \& Development, 26(3), pp. 403-421.

Morgan, C., 2015. Punk, DIY, and Anarchy in Archaeological Thought and Practice. Arqueologia Publica: Online Journal in Public Archaeology, Volume 5, pp. 123-146. 
Morgan, C., 2019. Avatars, Monsters, and Machines: A Cyborg Archaeology. European Journal of Archaeology, 22(3), pp. 324-337.

Nilsson Stutz, L., 2018. A Future for Archaeology: In Defense of an Intellectually Engaged, Collaborative, and Confident Archaeology. Norwegian Archaeological Review, 51(1-2), pp. 48-56.

Noddings, N., 1984. Caring: A Feminine Approach to Ethics and Moral Education.. Berkeley \& Los Angeles: University of California Press.

Péttursdòttir, T., 2017. Climate change? Archaeology and Anthropocene. Archaeological Dialogues, 24(2), pp. 175-205.

Piccini, A., 2007. A Survey of Heritage Television Viewing Figures. [Online]

Available at: http://britarch.ac.uk/sites/www.britarch.ac.uk/files/node-

files/research bulletin number 1 final.pdf

Pyburn, A. K., 2011. Engaged Archaeology: Whose Community? Which Public?. In: K. Okamura \& A. Matsuda, eds. New Perspectives in Global Public Archaeology. New York: Springer, pp. 29-41.

Pyburn, K. A., 2009. Practising Archaeology - As If It Really Matters. Public Archaeology, 8(2-3), pp. 161-175.

Rathje, W., 1979. Modern Material Culture Studies. Advances in Archaeological Method and Theory, Volume 2, pp. 1-27.

Richardson, L.-J. \& Almansa-Sánchez, J., 2015. Do you even know what public archaeology is? Trends, theory, practice, ethics. World Archaeology.

Ryzewski, K. \& Cherry, J. F., 2012. Communities and archaeology under the Soufrière Hill Volcano on Montserrat. Journal of Field Archaeology, 37(4), pp. 316-327.

Sørensen, M. L., 2000. Gender Archaeology. Cambridge: Polity.

Sørensen, T. F., 2017. The two cultures and a world apart: archaeology and science at a new crossroads. Norwegian Archaeological Review, 50(2), pp. 101-115.

Schadla-Hall, T., 1999. Editorial: Public Archaeology. European Journal of Archaeology, 2(2), pp. 147-158.

Schmidt, P. R., 2017. Contests between heritage and history in Tanganyika/Tanzania: Insights arising from community-based heritage research. Journal of Community Archaeology \& Heritage, 4(2), pp. $85-100$.

Shackel, P. A., 2007. Civic engagement and social justice: race on the Illinois frontier. In: B. J. Little \& P. A. Shackel, eds. Archaeology as a tool of civic engagement. Lanham, MD: Alta Mira Press, pp. 243-262.

Skeates, R., McDavid, C. \& Carman, J., 2012. The Oxford Handbook of Public Archaeology. Oxford: Oxford University Press.

Soto, G., 2016. Migrant Memento Mori and the Geography of Risk. Journal of Social Archaeology, 16(13), pp. 335-358.

Soto, G., 2016. Place making in Non-places: Migrant Graffiti in Rural Highway Box Culverts. Journal of Contemporary Archaeology, 3(2), pp. 121-294.

Spivak, G. C., 1988. Can the Subaltern Speak?. In: Marxism and the Interpretation of Culture. London: Macmillan, pp. 66-111.

Stottman, M. J., 2010. Archaeologists as Activists: can archaeologists change the world?.

Tuscaloosa: University of Alabama Press.

Supernant, K. \& Warrick, G., 2014. Challenges to Critical Community-Based Archaeological Practice in Canada. Canadian Journal of Archaeology, 38(2), pp. 563-591.

Taylor, J. \& Gison, L. K., 2016. Digitisation, Digital Interaction, and Social Media: Embedded Barriers to Democratic Heritage. International Journal of Heritage Studies, 5(1), pp. 1-13.

Thomas, S., 2014. Making archaeological heritage accessible in Great Britain: Enter community archaeology. In: S. Thomas \& J. Lea, eds. Public Participation in Archaeology. Woodbridge: The Boydell Press, pp. 23-33.

Trigger, B., 2006. A History of Archaeological Thought. 2nd ed. Cambridge, U.K.: Cambridge University Press.

Voss, B., 2016. Towards a Transpacific Archaeology of the Modern World. International Journal of Historical Archaeology, 20(1), pp. 146-174.

WHO, 2013. Global and regional estimates of violence against women Prevalence and health effects of intimate partner violence and non-partner sexual violence. [Online] 
Available at: https://www.who.int/reproductivehealth/publications/violence/9789241564625/en/

[Accessed August 2019].

Wylie, A., 2007. Doing Archaeology as a Feminist: Introduction. Journal of Archaeological Method and Theory, 14(3), pp. 209-216.

Wylie, A., 2019. Crossing a Threshold: Collaborative Archaeology in Global Dialogue.

Archaeologies: Journal of the World Archaeological Congress, 15(3), pp. 570-587.

Zimmerman, L., 2018. Changing archaeology's 'brand' would be helpful. Antiquity, 92(362), pp. 523-

524.

Zimmerman, L. J., 1989. Made radical by my own: an archaeologist learns to accept reburial. In: R. Layton, ed. Conflict in the Archaeology of Living Traditions. London: Unwin Hyman, pp. 60-67.

Zimmerman, L. J., Singleton, C. \& Welch, J., 2010. Activism and creating a translational archaeology of homelessness. World Archaeology, 42(3), pp. 443-454. 